\title{
UNION DIGITAL CENTRES OF TRISHAL UPAZILA: HOW FAR ENTREPRENEUR'S FINANCIAL COMPETENCY IS?
}

\author{
Shamima Akhter ${ }^{1}$ \\ Tanjil Ahmed $^{2}$
}

\begin{abstract}
Union Digital Centre (UDC), an innovative ingenuity of local government authority, represents a predominant nexus for efficient service delivery in rural areas. It has stimulated Information Technology (IT) and provided other internet based needful public and private services to the millions of underserved people's doorsteps at their convenience. By adopting this new dimension of entrepreneurship framework in rural economy, citizen friendly bottom-up development could be established. However, to introduce such set-up at periphery level, financial and technological support remains a big challenge. Hence, this study reveals the recent conditions and financial affairs of seven selected UDCs at Trishal Upazila. Both primary and secondary sources of data were collected from the studied area and in-depth interview of 23 individuals was taken in qualitative manner. It is observed that without generous financial supports it is very difficult to retain the financial solvency of the entrepreneurs. Sometimes, these massive financial liabilities, lack of logistic support, inadequate training and unskilled manpower are extensively responsible for gradual losing of interest to execute one stop shops services. Therefore, this study also suggested some necessary policy recommendations to strengthen UDC's activities by successfully executing the Public Private Entrepreneurship model in studied area.
\end{abstract}

Keywords: UDC, Local government, Entrepreneurship, Financial competency, IT

\footnotetext{
1 Shamima Akhter, is Assistant Professor, Department of Public Administration, Jagannath University, Dhaka-1100, email: akhter.shamima2020@gmail.com

2 Tanjil Ahmed, is Lecturer, Department of Public Administration and Governance Studies, Jatiya Kabi Kazi Nazrul Islam University, Trishal, Mymensingh, email:tanjilahmedtaj@gmail.com

Social Science Review [The Dhaka University Studies, Part-D], Vol. 38, No. 1, June 2021 DOI: https://doi.org/10.3329/ssr.v38i1.56528
} 


\section{Introduction}

The existing local government of Bangladesh is a decentralized body where representatives are elected by the local peoples in order to serve local administration and contribute to socio-economic development of the country. Local government (LG) can be expressed as a combination of processes which contribute to the overall development of a specific area and improvement of local standards required for establishing a harmonious integration of actions (PierreJean, 1994). According to Duane Lockard, local government is a public institution accredited to govern a defined range of public policies within a relatively small territory, which is a sub-division of a regional or national government (Siddiqui, 2005). It is an administrative body and the sub-system of central government which is established to provide services locally within a certain territory. There are two broad types of local government, such as rural local government which contains Union Parishad (UP), Upazila Parishad and Zila Parishad (district council) and urban local government which includes Municipality and City Corporation. Among these types, Union Parishad (UP) is the lowest tier of local government system, and it came into formal shape in the sub-continent during the last part of British rules. However, the existence of such kind of informal rural body was recorder even in the Vedic era (1500-1000 B.C), which looked after the safety, security and other social affairs including games and sports etc. at rural areas (Rahman, 2000). From the ancient period, Union Parishad (UP) has been taking part in an indispensable role to secure good governance, development planning, implementation, transparency, and accountability at rural areas in Bangladesh (Islam, 2017). To strengthen UP's activities more feasibly; the cutting-edge model of Union Digital Centre (UDC) was constituted to attain the target of the vision of Digital Bangladesh (DB) by 2021. Subsequently, the government of Bangladesh has taken the initiative to set up UDCs at each UP for providing one stop e-services to the rural people. This outlet basically provides information and other public and private services at union level. It is established under the direct jurisdiction of the Prime Minister's Office (PMO), with technical assistance from the United Nations Developed Program (UNDP) and United States Agency for International Development 
(USAID). Its operation is being overseen by the Access to Information (a2i) program. To overcome the existing dysfunctions of bureaucratic process in service delivery systems, UDCs are assisting rural citizens with its new avenue (Bakshi \& Rahman, 2016).

The new horizon of digitalization opened the door for the rural citizen to take services easily from their closest UDCs right away and smoothly. As a whole, the dramatic technological change in service delivery system occurred to put services at citizen's doorsteps, performing as a milestone towards achieving the goals of 'Digital Bangladesh' which is an inclusive vision of government. It has also empowered rural underserved people to access essential information and services in rapid, cost effective and simple ways. Otherwise, it is popularly known as TCV which means reducing time, cost, and visits. Merely, these are playing significant roles in bridging the digital divide and giving the benefits of ICTs to rural communities. UDCs could be the key component of information and service delivery to ensure sustainable development (Rahman,2016). However, due to lack of financial solvency, and technical shortfalls, UDCs cannot perform sustainably. By identifying the key factors which are affecting its sustainability, proper direction and financial supports are inevitable for the long-term development. This research also will give better suggestions and policy recommendation to overcome present phenomenon of immobility to foster activities of UDCs.

\section{Conceptual Definition}

\section{a) Union Digital Centre}

Union Digital Centre (UDC) is an innovative initiative of government that refers to a one-stop service centre where all kinds of physical and online services (government \& commercial) are provided to the grass-root people. In this regard, UDC runs under entrepreneur ownership and provides services to the local people with the assistance of Information Communication Technology (ICT) to execute e-government in Bangladesh (Saleheen, 2015).

\section{b) Entrepreneur}

An individual who set-up a new business, bearing all of the risks (financial and others), and enjoying all of the profits and rewards is called an entrepreneur (Hayes, 2021). Here entrepreneurs are interested local unemployed youths with 
basic literacy in computer and information technology and appointed by the respective UP chairman with the UNO's concern/recommendation. Each UDC consists of one male and one female entrepreneur appointed on PPP basis, and they are expected to become self-employed by earning from the delivery of services to the local citizens. Two alternative entrepreneurs are also appointed by the UNO to assist with the delivery process. These additional entrepreneurs are kept reserved for future appointment in absence of regular entrepreneurs. Some criteria are maintained while appointing entrepreneurs and these are age limit 30, minimum higher secondary level educational qualification, fundamental skills in computer and IT, ability to invest 50,000 Taka etc. Entrepreneurs have to follow UNO's instructions, coordinate with the UP Chairman and the UP secretary to run UDC. They have to report their monthly income, operational issues, and other problems to the UNO.

\section{c) Financial Competency}

In a general sense, financial competency refers to the financial sufficiency and financial sustainability of any organization. In this study, financial competency demonstrates the financial status of the UDCs in terms of assessing the organization's performance and its consistency. Where entrepreneur's financial competency is incorporated with income generation, capital inflow, investment, motivation and skill development, technical capacity and active monitoring and evaluation for its better sustainability. In other word, financial competency measure the auditing activities, cash management, financial risk management, debt management, and reporting activities of any organization (HRSG, 2021). If all the above parameters are met financial competency will be achieved enormously.

\section{Literature Review}

E-governance has been successfully connected to the components of Digital Bangladesh where Bangladesh has commenced various ICT initiatives for improving and extending countrywide public service delivery. These initiatives aimed to reforming government service delivery processes through involving entrepreneurs as well as private sectors under the innovative idea of UDCs 
(Hoque \& Mahiuddi, 2016). In Bangladesh, there are number of studies conducted on UDCs as one-stop service delivery outlets. Some of these relevant literatures are conversing here as follows;

Sarker assumed that UDCs are established within UPs as one-stop delivery points to reach local people easily and uproot all the existing problems related to access to information. It has the potential to reduce inaccessibility, cost, time, and distance, remove problems of intermediaries, irresponsiveness, lack of accountability and transparency in the delivery provision of information or services ( Sarker, 2013).

Faroqi depicts a study on the financial sustainability of the Union Digital Centres (UDC) in Bangladesh in terms of assessing entrepreneur's monthly income. The author explains that many entrepreneurs face income challenges i.e., minimum income and are forced to leave from entrepreneurship initiatives due to the lack of effective involvement of relevant partners. In this study, he argues that there are many influencing variables that affect the financial sustainability of UDC's entrepreneurs' income. For Instance, basic ICT equipment, advanced equipment, a range of services (certificates, e-government, and commercial type services), the extent of assistance from the government, effective involvement of relevant partners, scale of inputs from public partners, and the entrepreneur's investment, and entrepreneurial capacity along with people's participation, etc. have a significant effect in defining the monthly sustained income. Therefore, he also suggests that to ensure the financial sustainability of all UDCs and to reduce the dropouts of entrepreneurship, the increase in the units of these factors can play a significant role (Faroqi, 2015).

Nieuwoudt, Henning, and Jordaan (2017) elucidate a study on assessing the relationship between entrepreneurial competencies and financial performance. The authors conducted this study based on the qualitative approach. They principally emphasized on operating efficiency. The findings of the study explain that there is a positive relationship between entrepreneurial competencies and financial performance (Nieuwoudt, Henning, \& Jordaan, 2017). The authors principally focused on the correlation between entrepreneurial competencies and the financial performance of farmers However, the authors did not incorporate the financial competency or financial issues of the Union Digital Centre (UDC). 
Islam and Islam conduct a study on exploring the Shortcomings of the Union Digital Centre (UDC) in Bangladesh. The authors predominantly argue that Union Digital Centre (UDC) is an innovative initiative of the government that provides one-stop service to the doorsteps of every citizen in the rural areas in Bangladesh. In this regard, the authors demonstrate that as the newly set-up information centre, the principal purpose of UDC is to attain Vision 21 and Digital Bangladesh through ensuring digital service delivery to its client. As well, the authors explore the several challenges of UDC in terms of assessing the services (delay in providing service, insufficient staff-members, lack of quality, bureaucratic complexity, and so on), equipment limitations (lack of electric resources, poor internet connections) and insufficient budget, etc. Conversely, the authors provide several recommendations to address such challenges (Islam \& Islam, 2018). However, the authors did not particularly focus on the financial issues or financial competency of the UDC.

Razak, et. al. specified numerous ICT training services at UDCs such as; training in ICT related skills, development strategies, staff roles, production of content, marketing, evaluation, human resource management etc. These are important components for ensuring sustainability of the UDCs (Razak, et. al., 2010).

Additionally, Siddiquee and Faroqi noted some other reasons such as weak infrastructure, unskilled and insufficient human resource, and lake of proper cooperation from the local administration and UP etc. which have limited the capacity of UDCs to connect the rural citizen. In addition, unawareness of women, poor, and illiterate people to get benefits from UDCs also made it challenging (Siddiquee \& Faroqi, 2013).

While these studies concentrated on the overall sustainability to reach a breakeven point, then only few studies have explained individually about financial influences that hamper the income of entrepreneurs of UDCs. There is an urgent need to develop a model and test on financial viability as most of the externally funded UDCs faced challenges with the exit of donors (Kumar, 2005). Moreover, in Bangladesh no studies have previously focused on any forms of financial issues which are the key components of the UDCs. Hence, this study focuses on the financial viability of the UDCs for identifying the factors which are involved with the model and have influences on the inconsistency of entrepreneur's income. The study revealed that government onetime fund for start-up UDCs, 
poor financial capabilities of entrepreneurs, less investment, limited logistic supports and involvement of women entrepreneurs, minimum profit, lack of training, financial independence etc. are the major hindrances to run the UDCs successfully.

Since Trishal Upazila is one of the most focused geographic areas under Mymensingh division, close to the capital city (only 80 k.m from Dhaka), has gained high income opportunities so researchers are much interested to illustrate the main status and financial performance of the entrepreneurs of selected UDCs under this Upazila. Nevertheless, due to the higher education facilities, well communication systems, and growing industrial development activities etc. has extensively impact on overall nature of entrepreneur's financial viability. The findings of this qualitative study might be exemplary to explore the capacities and hindrances of the studied UDCs for updating action plans.

\section{Objectives of the study:}

The broad objective of this study is to assess the overall functions of UDCs and how it could manage the funds to provide the prompt services at their locality. The specific objectives are:

a) To explore the financial competency and challenges faced by the entrepreneurs of the selected UDCs at Trishal Upazila.

b) To make some policy recommendations for the sustainable service delivery of conjugated area.

\section{Methodology}

The study was based on the qualitative approach under exploratory in nature. The data were collected from both primary and secondary sources. Primary sources of data were collected by in-depth interviews with semi-structured questioner of total 23 individuals of which 10 UDC's entrepreneurs, 4 UP Chairman, 4 UP secretaries, 1 UNO, 1 Deputy Commissioner, and 3 Deputy Secretaries of the Ministry of Local Government \& Rural Development, Local Government Division (LGD). Secondary sources of data were collected from various published articles, books, research papers, reports and other materials related to the research issues. Finally, a qualitative approach is used to analyse and interpret the response. 


\section{Sample}

Sample size of the present research is demonstrated in Table 1 below:

Table 1: The Sample Size for Qualitative Research

\begin{tabular}{|c|c|c|c|}
\hline $\begin{array}{l}\text { Union Digital } \\
\text { Centre (UDCs)/ } \\
\text { Studied Area }\end{array}$ & $\begin{array}{c}\text { Criteria of } \\
\text { Respondents }\end{array}$ & $\begin{array}{c}\text { No. of } \\
\text { Respondents }\end{array}$ & $\begin{array}{l}\text { Total No. of } \\
\text { Respondents }\end{array}$ \\
\hline $\begin{array}{l}\text { Ameerabari UDC } \\
\text { Kanihari UDC } \\
\text { Harirampur UDC }\end{array}$ & \multirow[b]{2}{*}{ UDC Entrepreneurs } & $\begin{array}{l}2 \text { (from each } \\
\text { UDC) }\end{array}$ & $(2 \times 3)=6$ \\
\hline $\begin{array}{c}\text { Trishal UDC } \\
\text { Bailor UDC } \\
\text { Danikhola UDC } \\
\text { Moothbari UDC }\end{array}$ & & $\begin{array}{l}1 \text { (from each } \\
\text { UDC) }\end{array}$ & $(1 x 4)=4$ \\
\hline \multirow[b]{2}{*}{$\begin{array}{l}\text { Union Parishad } \\
\text { (Trishal) }\end{array}$} & UP Chairman & 4 & 4 \\
\hline & UP Secretary & 4 & 4 \\
\hline $\begin{array}{c}\text { Deputy } \\
\text { Commissioner's } \\
\text { Office } \\
\text { (Mymensingh) }\end{array}$ & $\begin{array}{c}\text { Deputy Commissioner } \\
\text { (DC) } \\
\text { (Mohammad Enamul } \\
\text { Hauque) }\end{array}$ & 1 & 1 \\
\hline $\begin{array}{c}\text { Ministry of } \\
\text { LGRD, } \\
\text { Local } \\
\text { Government } \\
\text { Division (LGD) }\end{array}$ & $\begin{array}{c}\text { Deputy Secretary (DS) } \\
\text { (UP section -1,Abu Zafar } \\
\text { Ripon } \\
\text { UP section -2, Md. } \\
\text { Akbar Hossain Planning- } \\
\text { 3, Reyasat - Al Wasif) }\end{array}$ & 3 & 3 \\
\hline $\begin{array}{l}\text { Upazila Parishad } \\
\text { (Trishal) }\end{array}$ & $\begin{array}{l}\text { Upazila Nirbahi Officer } \\
\text { (UNO) } \\
\text { (Mostafizur Rahman) }\end{array}$ & 1 & 1 \\
\hline \multicolumn{3}{|c|}{ Total Respondents } & 23 \\
\hline
\end{tabular}

Source: Compiled from the findings of the interviews 


\section{Findings and Discussions of the Study} i) Entrepreneur's Profile:

The academic qualifications and professional experiences of the entrepreneurs have important role in service delivery and precondition for financial competencies of the Union Digital Centre (UDC). It is fund that most of the entrepreneurs are young, and their educational qualification is not less than HSC level. The biographies of the entrepreneurs under this study are listed in table 2 .

Table-2: Entrepreneur's profile of selected UDCs:

\begin{tabular}{|c|c|c|c|c|}
\hline $\begin{array}{l}\text { Sl. } \\
\text { No. }\end{array}$ & $\begin{array}{l}\text { Name of the } \\
\text { Entrepreneur }\end{array}$ & Qualification & Age & Studied Area \\
\hline 1. & Kamrun Nahar & $\begin{array}{l}\text { MSS in Political } \\
\text { Science }\end{array}$ & Age-28 & \multirow{2}{*}{$\begin{array}{l}\text { Harirampur Union } \\
\text { Digital Centre }\end{array}$} \\
\hline 2 & Riadul Islam & HSC & Age-31 & \\
\hline 3 & Mazharul Islam & $\begin{array}{l}\text { MSS in Political } \\
\text { Science }\end{array}$ & Age-35 & $\begin{array}{l}\text { Trishal Union Digital } \\
\text { Centre }\end{array}$ \\
\hline 4 & Mehedi Rony & BSS in History & Age-30 & \multirow{2}{*}{$\begin{array}{l}\text { Kanihari Union } \\
\text { Digital Centre }\end{array}$} \\
\hline 5 & Umme Kulsum & $\begin{array}{l}\text { BSS in Islamic } \\
\text { Study }\end{array}$ & Age-32 & \\
\hline 6 & $\begin{array}{l}\text { Md. Anayet } \\
\text { Hossain Rojen }\end{array}$ & $\begin{array}{l}\text { MSS in Political } \\
\text { Science }\end{array}$ & Age-36 & $\begin{array}{c}\text { Bailor Union Digital } \\
\text { Centre }\end{array}$ \\
\hline 7 & Khaleda Begum & HSC & Age-29 & $\begin{array}{l}\text { Danikhola Union } \\
\text { Digital Centre }\end{array}$ \\
\hline 8 & Manik Mia & Degree & Age-33 & \multirow{2}{*}{$\begin{array}{l}\text { Ameerabari Union } \\
\text { Digital Centre }\end{array}$} \\
\hline 9 & Salma Khatun & HSC & Age- 30 & \\
\hline 10 & Taslima & Degree & Age-26 & $\begin{array}{l}\text { Mootbari Union } \\
\text { Digital Centre }\end{array}$ \\
\hline
\end{tabular}

Source: Compiled from the findings of the interviews 


\section{ii) Entrepreneurs Operational Services}

The recent trends of 'Digital revolution' influence every sphere of people's life both in first and rest of the world. Government of the People's Republic of Bangladesh inaugurated Union Information and Service Centres (UISCs) on November 11, 2009. In 2014 it was renamed as Union Digital Centres (UDCs) in all unions across the country. UDCs provide Information, Commercial and Government based services through using E-governance model for enhancing one stop services. The major categories of services offered by the UDCs are briefly illustrated in Figure 1 and discussed in detailed below:

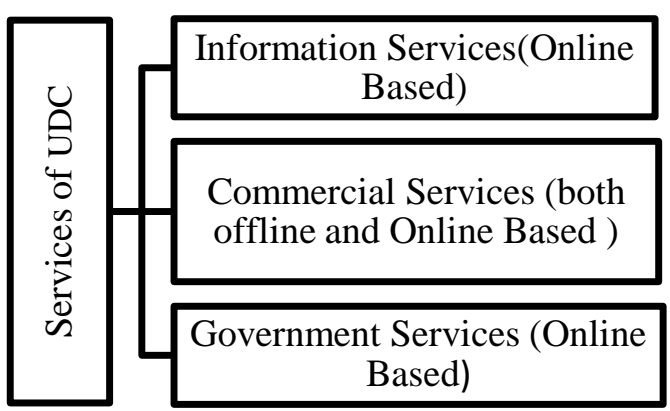

Figure-1: E-governance service model (2015)

Source: Retrieved from Access to information: http;//www.a2i.gov.bd

\section{(a) Information Services of UDC}

The general objective included building consciousness among the people about eservices offered by the government. It disseminated the agriculture, health, education, law and human rights, tourism, environment, and disaster management related information to the people for making citizen's life more comfortable and easier. Figure 2 represents the information services provided by the UDCs: 


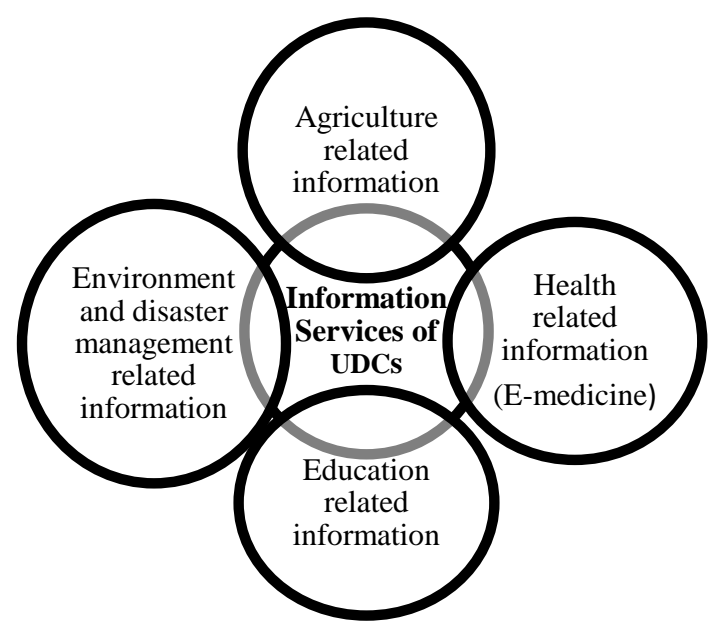

Figure 2: Information based Services of UDC

(Source: Author's Illustration)

\section{(b) Commercial services of UDC}

The diverse private and commercial services are provided by the UDCs at union level. By entrepreneur's own initiatives it helps the customers to take their pictures for multipurpose uses. It also plays significant commercial role by giving online banking services to the people and other facilities such as; photocopy, scanning, email, internet browsing, computer compose, talking with Skype etc. Building partnership between various private organizations like bank, insurance company etc. is an indispensable work done by UDCs. Commercial services offered by the UDCs are depicted in Figure 3 below. 


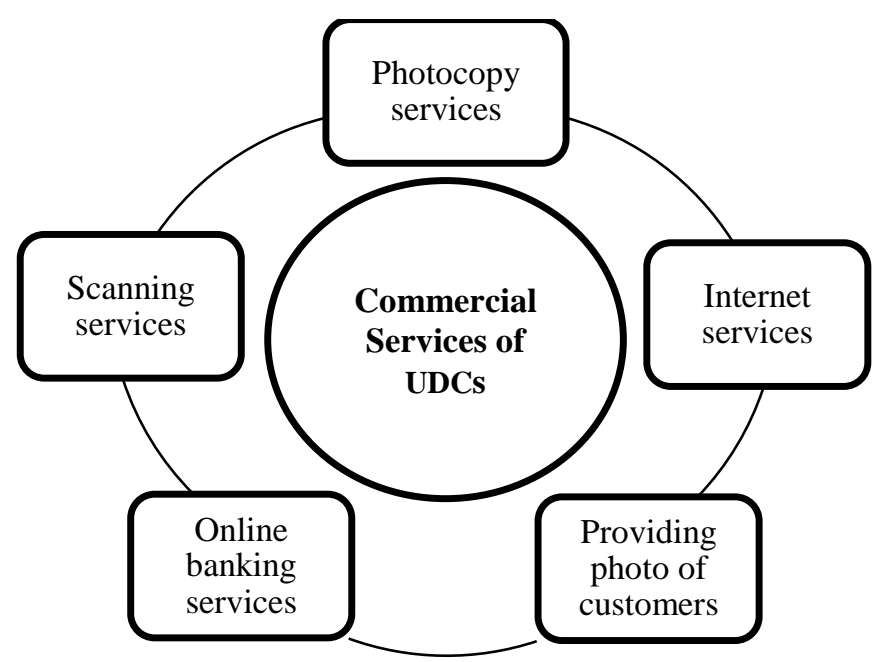

Figure 3: Commercial Services of UDC

(Source: Author's Illustration)

\section{(c) Government Services of UDC}

Online birth registration, death certificate, citizenship certificate, character certificate, population census data entry, downloading different kinds of government forms, government circulars and notices, online university admission, examination results, TR / Kabikha information, passport form, etc. are common government services which are served by UDCs.

\section{iii) Key Service Costs of selected UDCs at a Glance}

Public Private Partnership (PPPs) plays pivotal role to assess entrepreneur's overall performance. It describes a government service or private business venture which is funded and operated through a partnership of government and one or more private companies. To fostering economic and social development, Government of Bangladesh has been turning to the private sector for the delivery of infrastructure services such as education; health; water and sanitation. In particular, the emerging cross-country evidence suggests that the specific combination of public financing and private provision may be a promising option. This empirical study on selected UDCs identified enormous role to provide service in the periphery level. Therefore, services and respective costs have been listed in table 3 . 
Table 3: Key Services and Costs of Selected at a Glance

\begin{tabular}{|c|c|c|c|c|c|}
\hline $\begin{array}{l}\text { Sl. } \\
\text { No. }\end{array}$ & Services & Unit & $\begin{array}{l}\text { Unit of Price } \\
\text { BDT (Taka) }\end{array}$ & $\begin{array}{c}\text { Entrepreneurs } \\
\text { Profits } \\
\text { (Approximately) }\end{array}$ & $\begin{array}{c}\text { Total } \\
\text { Unit } \\
\text { of } \\
\text { Price }\end{array}$ \\
\hline 1. & $\begin{array}{l}\text { Online birth } \\
\text { registration (Infant } \\
\text { who are not more } \\
\text { than } 45 \text { days) }\end{array}$ & 1 & $\begin{array}{l}\text { No } \\
\text { government } \\
\text { fees }\end{array}$ & $\begin{array}{l}\text { Printing Charge } \\
\text { Tk. 30-50 }\end{array}$ & Tk. 50 \\
\hline 2. & $\begin{array}{c}\text { Online birth } \\
\text { registration } \\
\text { (General and adult } \\
\text { people })\end{array}$ & 1 & $\begin{array}{l}\text { Government } \\
\text { fee Tk. } 50\end{array}$ & $\begin{array}{l}\text { Tk. } 50 \text { is } \\
\text { entrepreneur's } \\
\text { profit }\end{array}$ & $\begin{array}{l}\text { Tk. } \\
100\end{array}$ \\
\hline 3. & $\begin{array}{l}\text { Online based Death } \\
\text { certificate }\end{array}$ & 1 & $\begin{array}{l}\text { Government } \\
\text { fee Tk. } 50\end{array}$ & $\begin{array}{l}\text { Tk. } 50 \text { is } \\
\text { entrepreneur's } \\
\text { profit }\end{array}$ & $\begin{array}{l}\text { Tk. } \\
100\end{array}$ \\
\hline 4. & $\begin{array}{l}\text { E-Porcha Services } \\
\text { for land related } \\
\text { documentation }\end{array}$ & 1 & $\begin{array}{l}\text { Government } \\
\text { fee Tk. } 60\end{array}$ & $\begin{array}{l}\text { Composing Tk. 40- } \\
50\end{array}$ & $\begin{array}{l}\text { Tk. } \\
110\end{array}$ \\
\hline 5. & $\begin{array}{l}\text { Citizenship } \\
\text { certificate \& } \\
\text { inheritress } \\
\text { certificate }\end{array}$ & 1 & $\begin{array}{l}\text { No } \\
\text { Government } \\
\text { fees }\end{array}$ & $\begin{array}{l}\text { Printing cost Tk. } \\
25-30\end{array}$ & Tk. 30 \\
\hline 6. & Trade License & 1 & $\begin{array}{l}\text { Up to Tk. } \\
200 \text { based on } \\
\text { the business } \\
\text { nature (for } \\
\text { example- } \\
\text { Fancy Goods } \\
\text { Business) }\end{array}$ & $\begin{array}{c}\text { Printing cost Tk. } \\
30\end{array}$ & $\begin{array}{l}\text { Tk. } \\
230\end{array}$ \\
\hline 7. & Correction of NID & 1 & $\begin{array}{c}\text { Government } \\
\text { fee Tk. 230 } \\
\text { (General) }\end{array}$ & $\begin{array}{l}\text { Printing and } \\
\text { composing cost } \\
\text { Tk. 40-60. }\end{array}$ & $\begin{array}{l}\text { Tk. } \\
2990\end{array}$ \\
\hline 8. & E-passport check & 1 & Free & $\begin{array}{c}\text { Internet cost Tk. } \\
20\end{array}$ & Tk. 20 \\
\hline 9. & $\begin{array}{l}\text { Documents } \\
\text { Compose }\end{array}$ & 1 & Free & $\begin{array}{l}\text { Per page compose } \\
\text { charge Tk. } 25\end{array}$ & Tk. 25 \\
\hline
\end{tabular}




\begin{tabular}{|l|c|c|c|c|c|}
\hline 10. & Job applying & 1 & Free & $\begin{array}{c}\text { Per applying Tk. } \\
50-70\end{array}$ & Tk. 70 \\
\hline 11. & Photocopy & 1 & Free & Per page Tk. 2 & Tk. 2 \\
\hline 12. & Internet browsing & $\begin{array}{c}1 \\
\text { (Hour) }\end{array}$ & Free & Tk. 30-40 & Tk. 40 \\
\hline 13. & Visa checking & 1 & Free & $\begin{array}{c}\text { Internet charge Tk. } \\
\text { 30-40 }\end{array}$ & Tk. 40 \\
\hline 14. & Holding Tax & 1 & $\begin{array}{c}\text { It varies } \\
\text { based on } \\
\text { house type, } \\
\text { usually Tk. } \\
100 \text { to 300 } \\
\text { (for instance- } \\
\text { Tin shade } \\
\text { house Tk. } \\
150, \text { half- } \\
\text { building Tk. } \\
\text { 200, building } \\
\text { Tk. 300) }\end{array}$ & $\begin{array}{c}\text { Preparation charge } \\
\text { Tk. 20 }\end{array}$ & $\begin{array}{c}\text { Varies } \\
\text { time to } \\
\text { time }\end{array}$ \\
\end{tabular}

(Source: Compiled from the findings of the interviews)

\section{iv) Income and Investment of the Entrepreneurs}

Income and investment are key indicators of the entrepreneur's competency which includes motivation, computer skill, marketing qualities, pro-activeness and understanding capabilities of risks of the business. An entrepreneur's accumulated savings from last year is considered as this year's investment. During the interview sessions, it was found that income and investment are very interrelated factors. Sometimes they get less profit and failed to invest again from their own income to expand their business. Most of the local people are privileged by taking one stop services such as; online based birth and death certificate, National Identity (NID) Card correction, citizen certificate, character certificate, power of attorney certificate, VGD, VGF card and email, photocopy, internet browsing, video conference, E-Porcha for land, passport application, visa check etc. with simplified payment procedure. Day by day it has gained popularity among the population, so they are taking services from UDCs instead 
of other local business centre. Therefore, it seems most of the entrepreneurs of UDCs maximize their profit margins from their day-to-day services. However, an entrepreneur named Mr. Mehedi Rony at Kanihari Union Digital Centre (UDC) opined:

Compared to the profits, it is a big financial challenge for us (UDC). Because in the beginning of a UDC formation, the government has only provided us a platform and some initial setup, then we (me and another women entrepreneur) run this organization like a business store. At times, we do the entrusted work of the UP Secretary at no cost. For instance, we do not get any profit in terms of doing VGD enlistment, VGF enlistment, and creation of other enlistment activity which is suppose fall under the work description of UP. Moreover, we work for free of cost to update the information on the website of the UP. In all these cases, we are not able to make a reasonable profit by investing.

According to the other entrepreneur's view, most of the UDCs are getting some work contracts from government offices, UP offices, LGSP projects, Land Transfer Projects, PPP projects and other sources. UP Secretary Mr. Anowar Hossain of the Boilor UP mentioned:

UDCs could obtain income from other alternative source, because they have enough scope to add services based on their own ability and capacity such as; online and mobile banking, digital marketing etc.

\section{v) Financial Autonomy of UDCs}

The introduction of UDCs at grass root level is a precondition of financial decentralization of local government. The extent of fiscal powers exercise found very limited in various tiers of local governments. There is no macro level clarity regarding the aggregate number of resources available to different tiers of Local Government Institutions (LGIs) like Union Parishad as well as Union Digital Centre (UDC) (Bhattacharya, et. al. 2013). Independent Financial devolution will help the entrepreneurs to minimize finance crisis beyond the government strict conditions and make the service delivery system more prompt. However, most of the interviews of entrepreneurs informed that entrepreneurs have no financial independence. Therefore, independent financial devolution must have valid purpose to ensure effective service delivery and profit maximization of UDCs at union level. 


\section{vi) Skilled Manpower and Multi-staged technical capacity}

Entrepreneurs were identified by the UP chairman and confirmed by local administrators. Interviews with management confirmed that recruitment prerequisites relating to minimum qualification, investment capacity and contract enforcement were not followed strictly because of computer skill, motivation of entrepreneurs, and capability of investment were rare. Many operators were not able to commit to the task full-time and low-income entrepreneurs cannot invest further to expand the business. Entrepreneurs of the selected UDCs have opined that the multi-staged technical problems such as slow internet speed, server problem, frequent load-shedding, shortage of manpower, shortage of equipment, poor infrastructures and less consciousness of service seekers were observed in the studied area. They could not even carry out the regular work e.g., especially failure to provide birth certificate to the people on due time. Besides, UDCs have load-shedding problems which is one of the significant technical problems identified in almost all the UDCs One of women entrepreneur named Mrs. Khaleda Begum at Danikhola Union Digital Centre (UDC) pointed :

After starting work as an UDC entrepreneur, I received training approximately seven times organized by the Mymensingh DC office. From these trainings, I learned how to update the information on the website, how to make birth and death certificates and to provide other internet-related services. But irregularly in arranging such kind of events creates a lot of knowledge gap.

\section{vii) Relationship between UP members and UDC Entrepreneurs}

The UP and central administration have delegated little power to entrepreneurs though they are considered ambassadors of the projects. They are placed under the control of the UP secretary and treated as part-time employees who can be dismissed at will of UP authority. Though UDCs are independent body, most of the time UP chairman and UP secretary forces the entrepreneurs to do their work without any payment. Sometimes, they seem to be main workforce of UP rather than UDC. The above observation was shared by the UNO of Trishal Upazila while interviewing. People from different sectors are involved in service delivery systems of UDCs. A male entrepreneur named Mr. Manik Mia at Ameerabari Union Digital Centre (UDC) stated:

Union Parishad Chairman and UP secretary would observe the overall activities and primary issues of the UDC. But from my own experience, I want to say that 
they do not provide any solution regarding comprehensive issues where the financial aspect is interrelated. Such as buying or repairing the IT equipment e.g., computer, digital scanners, photocopy machine, printer, etc. Besides, an audit officer visits the UP Secretary office yearly (in Jun or July) to explore the financial reporting of the UDC's revenue. Sometimes, Upazila Nirbahi Officer (UNO) visits the UDC to know the existing status of the UDCs. But I think the monitoring activities of such authority are not enough to evaluate the practical challenges of the UDC.

Another women entrepreneur named Mrs. Salma Khatun at Ameerabari Union Digital Centre (UDC) stated:

Still now UDC struggles with many problems. We can earn less than other ICT serving enterprises in case of providing the same services. In some cases, we also face deceitful activities. For example, some people take services from UDC without any payment based on the reference of political leaders. Besides, we have no salary opportunity as we are entrepreneurs. As a result, we are suffering from financial crises.

\section{viii) Status of Women Entrepreneurs}

In our country, most of the village women are socially backward and patriarchy dominated which hinders their emancipation everywhere. Financial vulnerability and social taboo made them restricted to give their best at their workplace in productive way. Additionally, our rural society predominately discourages women's participation in outdoor activities for their income generation (Hasan, 2007). And this restriction also extremely maintained on married women by taking permission from their husband and in-laws (Hasan, 2020). In this context, our findings also reveal that in some cases, female entrepreneurs of UDCs faced difficulties to go outside to complete their work because of conservative mind-set of community. So that they could not perform well if compared to the male counterpart. Besides, they were not present in their workplace regularly. Sometimes, they are not even able to meet the monthly financial targets. Indeed, a satisfactory number of women entrepreneurs are participated in both UDCs, but very few of them are skilled and literate. Moreover, practicing such pattern (one female and one male) of structural gender balance only ensure the participation of women in UDCs rather actual financial benefits. To achieve its functional goals, government and private organization should introduce innovative skill-based training especially for young women who are working on it. 


\section{Challenges}

From the collected qualitative data from several entrepreneurs, UP chairman, UP secretary, DC, UNO, and Deputy Secretary of LGD by conducting in-depth interviews that incorporate the practical issues of the Union Digital Centre (UDC) at field levels:

\section{i) No fixed government fund for UDCs}

From the very beginning, the journey of UDC was based upon entrepreneurship model where government helped each entrepreneur at once by giving some logistic, infrastructural, and financial support to survive in the competitive market economy. The main essence was to make the youth as businessman to run their business as well as serve government's bundle of services at cheapest cost, within short time and fewer visits (TCV). Almost all entrepreneurs, UP secretaries and UNO of all UDCs think that sufficient and permanent government allotment could secure their financial strength, quality service mechanism and make it more reliable to the service seekers. Although, Deputy Commissioner (DC) of the Mymensingh Division and two Deputy Secretaries of the Local Government Division (LGD) argued that if they are paid in such a way, they will be depended on only government fund and not act as a change maker of their own fate. They also added that if government does so it will also lose its prime motto, an independent generation of unemployed youths to boost up the income generation at grass root level.

\section{ii) Lack of knowledge about service bundle}

UDC is the latest innovation of local government. There are bundle of government services given by UDCs at cheapest cost. But unfortunately, several respondents inform that most of the community people have no idea about what services they can get from these UDCs. To make it more effective and trustworthy institution among the service receivers, it is important to know what the quick services are given by UDC in minimal cost in one visit. One of the entrepreneurs of Trishal Union Digital Centre (UDC), Mr. Mazharul Islam opined:

Local people take one-stop services (online-based birth and death certificate, computer-based NID Card correction, citizen certificate, character certificate, email service, photocopy, internet browsing, video conference, E-Porcha for land, passport application, visa check, etc.) from UDC in terms of little and easy 
pay. Service seekers payment is the main source of UDC profit from which we carry out our daily cost and profit.

Interestingly, our study also found that the service providers (entrepreneurs) have severe limitations of knowledge about plenty of services offered by UDCs. Therefore, greater engagement with the rural people and make them more aware about UDCs services will ensure great sources of revenue collection and entrepreneur's financial profits as well.

\section{iii) Inadequate capital inflow}

Financial crisis of entrepreneurs restricted the working capacity of UDCs. It causes inability to purchase IT equipment tools such as; computers, scanners, photocopy machine and camera etc. Nevertheless, slow internet speed has caused major problem. Besides, almost all entrepreneurs, UP chairman and Secretary of the selected UDCs contended, financial crisis and inadequate financial capital inflow had hampered the working capacity and total development of UDCs. It is highly suggested by the managerial officials of level interviews to be more engaged with private sectors for its financial support.

\section{iv) Absent of dynamic entrepreneurship}

Gradually improving trend of effective business model skills enforce entrepreneurs to cope with different programs such as financial management, internet and computer technologies, device management, consumer, and marketing policy knowledge as well as overall competency level. With the help of ICT- based applications entrepreneurs become more competent and interactive person. Whereas one of our interviewees, DC, Mymensingh pointed that there is huge absence of proactive personality prevailing in most of the UDCs. He also added that if there are competitions among the entrepreneurs, they could achieve more profit from various sources rather than seeking government subsidy.

\section{v) Lack of Performance monitoring}

To monitor the progress of UDC operations, an online monitoring tool was created by the A2I which is known as the UDC Activities Management System. Entrepreneurs are required to upload a daily activity report. This allows centralized monitoring by the A2I, Cabinet Division, LGD and the Deputy Commissioner (DC) of the district. However, active performance monitors and 
information sharing by central government through field visits and online data collection the on UDCs activities have been observed insufficient in studied area. Therefore, working environment of both UDC's were found lethargic, unprofessional, and ineffective. To make it more vibrant, operational, and service-oriented monitoring and evaluation system should be instigated. A male entrepreneur named Mr. Manik Mia at Ameerabari Union Digital Centre (UDC) stated:

Union Parishad Chairman and UP secretary observe the overall activities and primary issues of the UDC. But from my own experience, I want to say that they do not provide any solution regarding comprehensive issues where the financial aspect is interrelated. Such as buying or repairing the IT equipment-computer, digital scanners, photocopy machine, printer, etc. Besides, an audit officer visits the UP Secretary office yearly (in June or July) to explore the financial reporting of the UDC's revenue. Sometimes, Upazila Nirbahi Officer (UNO) visits the UDC to know the existing status of the UDC. But I think the monitoring activities of such authority are not enough to evaluate the practical challenges of the UDC.

\section{vi) Limited logistic supports}

Modern technology-based outlet UDC will uplift its credibility amidst the citizen in every single accomplishment. Therefore, the modern equipment and tools such as; high configuration laptops; scanners; photocopy machines; cameras and a certain internet connection are required for smooth functioning of its activities successfully. Nevertheless, due to the frequent load-shedding and slow internet speed, hassle-free services become inconsistent. Therefore, government should take necessary steps to ensure better continuity of power supply and reliable internet services at each UDC. However, the wave of digitalization introduced broadband internet connectivity with high-speed compatibility through its optical fibre in every sub-district council of Bangladesh ("Bangladesh's Digital Revolution", 2017 ). So, it would be better to set up such kind of connectivity in a single network in UDCs through optical fibre. One of the male entrepreneurs named Mr. Riadul Islam at Harirampur Union Digital Centre (UDC) states:

UDC faces several challenges in terms of finance, political pressure, domination of UP chairman, and equipment support. I face immense financial challenges when any equipment damages. Because Union Parishad does not provide any funds to repair the damaged equipment such as computers, printers, scanners, photocopy machines, etc. another woman entrepreneur and I bear all repairing 
costs. I know that I am working here as an entrepreneur, but I do not enjoy the full autonomy as an entrepreneur due to unexpected political pressure and Union Parishad chairman's domination. For instance, most of the time several local people take the free services from me by showing their political power. And said they are the people of the chairman, members, or UP secretary. Sometimes I had to do the Union Parishad chairman's recommended tasks free of cost. I think, in such cases, I am a victim of exploitation by those people. Correspondingly, I think, we have no financial security. Together with all things, we are very concerned about our business at UDC.

\section{vii) Limited Training for the entrepreneur's}

Entrepreneurs training are vital issue to improve the quality of services. It is not only developing the performances of the entrepreneurs but also enhanced the efficiency and effectiveness in terms of giving services to the citizen. It is often observed that entrepreneurs misbehave with the service seeker due to the overload and working stress. For the better service delivery; gaining professionalism and improve their outcomes, regular training and workshop initiatives is highly recommended in studied area. A women entrepreneur named Mrs. Umme Kulsum at Kanihari Union Digital Centre UDC stated:

After taking the responsibility of entrepreneur, we face some challenges due to domestic activities i.e., household work, and taking care of baby, etc. Moreover, many women do not show their interest to be the entrepreneur due to lack of training and IT knowledge. As well, due to patriarchal social structure, lack of ability to take risks if compared to men, lack of professionalism of running a business, and high risks, women do not come forward to be entrepreneurs. Moreover, I think there are many risks of women enterprisers regarding making a profit than managing entrepreneur profession since we are not skills like men.

\section{Policy Recommendations}

There are some key recommendations made based on our findings and interviews which would make UDC financially more competent, acceptable, and service oriented.

1. The 'Annual Best Performer Award' in local administration at national and district levels in three categories such as; management officials, local representatives and entrepreneurs should be popular to create competition among them. It also motivates the entrepreneurs to be vibrant incoming capital inflow in UDCs. 
2. Fruitful training can be introduced to improve the existing condition of manpower to avail its highest financial benefits. Therefore, Department of Youth Development, Upazila and district level computer literacy vocational training could be arranged frequently by concern UPs and UNO authority.

3. UDCs are also faces poor infrastructures and shortage of modern equipment. Establishing high bandwidth internet services and continues electricity can deliver regular services in a speedy way.

4. This study found that a significant number of entrepreneurs (especially female) have tendency to be absent in their workplace and some UDCs are entirely without female entrepreneurs. In this regards, regular monitoring with visit by the UNO can improve the situation.

5. To facilitate the investment, entrepreneurs can be granted loans with minimum interest by the government after assessing their track records. Motivational skill of entrepreneurs should be improved which will enforce them to do better performance in financial improvement of concern UDCs.

6. Manpower should be transformed to mindful intellectual and develop themselves as a 'Local Economic Ambassador' not only employee of the UDCs. Hence, one should create more entrepreneurs to eradicate unemployment from each union. Moreover, to set up skilled manpower it is essential to recruit entrepreneurs by wider advertisement and ensuring basic criteria mentioned in prescribed policy such as; age limit, gender, and educational qualification and investment capacity.

7. To elevate the UDCs income and prompt service delivery, publicity is highly recommended in studied area. Displaying citizen charter on the board in front of each UP Office premise should be ensured.

8. Finally, fixed funding and salary like other government employees could restrict them from becoming an entrepreneurs or businessman.

\section{Conclusion}

In a present financial decentralized local government system UDC has been considered a key driving force and become more popular to the people over time. The main objective of Union Digital Centres (UDC) is to deliver various governments, private and local government services to the people's doorsteps to 
establish it a core public affiliation. The specific purposes of the UDC have to connect the UP to the global and national network and make it the vibrant knowledge-based institution, ensure easy access of common citizen to essential information and services and ICT-based infrastructure in local government to develop local entrepreneurship (a2i, 2011). Therefore, insufficient finance by entrepreneurs, lack of training, financial dependency, low internet speed, inadequate modern equipment and logistic support, apathy to provide services, and unskilful human resources etc. cause major hindrances to run the UDCs successfully in the studied area. Despite these limitations, it become more popular day by day at the union level as mass is getting absolute benefit from such hassle-free services. Moreover, concerned government units and other stakeholders could play significant role by establishing high-speed broadband internet connectivity. It has also seen that a satisfactory number of female entrepreneurs wanted to do training to make them more adaptable with the technological advancement. However, irrespective to gender all entrepreneurs must need more training to enhance their ICT- based knowledge and better service delivery. With a view to fostering the performance of UDC, it is urgent to remove all barriers of UDCs based on suggested guidelines. Most importantly, financial competency of entrepreneur will strengthen mobility of the UDC's and contribute to escalate rural economic development of the country by ensuring proper implementation of e-governance in utmost level.

\section{References:}

a2i report (2011). Strategic priorities of Digital Bangladesh. Retrieved from https://a2i.gov.bd/publication/strategy-digital-bangladesh/ (Accessed on December 20, 2020).

Bakshi R. K, \& Rahman, T. (2016). Expansion of Selected Services through Union Digital Centres, Bangladesh Priorities, Copenhagen Consensus Centre.

Bangladesh's Digital Revolution. (2017). Retrieved from May 11, 2021, from https:// cri.org.bd/publication/digital-revolution/Bangladesh\%27s\%20Digital\%20Revolution.pdf

Bhattacharya, D., Monem, M., Ahmed, S., Rezbana, U.S., Gonsalves, M. Hossain, M. A., Siddique, M.A.I. (2013). Finance for Local Government: An Elusive Agenda. Retrieved from the Centre for Policy Dialogue website: http://www.cpd.org.bd/downloads/Session1_DB.pdf

Faroqi,M. G. (2015). Financial sustainability of union digital Centre in Bangladesh. Journal of Developing Areas, 49(6), 61-73. https://ideas.repec.org/a/jda/journl/vol.49year2015 issue6pp61-73.html

Hasan, S. (2007). Women in Bangladesh Local Government: A Study of Gram Sarkar. Dhaka: A H Development Publishing House.

Hasan, S. (2020). ICT Policy for Digital Bangladesh: Status of Compliance and Challenges" in Ahmed, N. (ed.), Public Service Delivery in Bangladesh: Parliament, Public Policy and Local Government (pp.171-188), Dhaka, The University Press Limited. 
Hayes, A. (2021). Entrepreneur. Investopedia. https://www.investopedia.com/terms/e/ entrepreneur.asp/ (Accessed on June 17, 2021).

Hoque, S. M. S., \& Mahiuddi, K. (2016). Union Digital Centre (UDC) and Reduction of Digital Gap: An Analysis on Users' Perception. International Conference on Inclusiveness Governance in South Asia, organized by Public Administration and Governance Research Network and the University of Chittagong. Chittagong: BIAM, Dhaka.

HRSG. (2021). Accounting Competencies and Finance Competencies - Examples, Key Skills \& Lists, HRSG. Human Resource Systems Group. https://www.competencies.co/competencies/ accounting-finance-competencies/ (Accessed on July 20, 2020).

Islam, M. T. (2017, November 07). Understanding the Effectiveness of Union Parishad Standing Committee: A Perspective on Bangladesh [Blog post]. Retrieved from https://blogs.lse.ac.uk/ southasia/2017/11/07/understanding-the-effectiveness-of-union-parishad-standing-committeea-perspective-on-bangladesh/

Islam, N. M., \& Islam, M. A. (2018). Exploring the Shortcomings of Union Digital Centre (UDC) in Bangladesh: A Study. Indian Journal of Library and Information Science, 12 (2), 95-100.

Kumar, R. (2005). eChoupals: A Study on the Financial Sustainability of Village Internet Centres in Rural Madhya Pradesh. Information Technologies and International Development, 2 (1), 4573

Nieuwoudt, S., Henning, J. I. F., \& Jordaan, H. (2017). Entrepreneurial competencies and financial performance of farmers in South Africa. South African Journal of Economic and Management Sciences, 20 (1), 1-13. https://doi.org/10.4102/sajems.v20i1.1640

Pierre-Jean, J. (1994). Guide $d$ 'approche des institution locales (GAIL). Geneva: Institut Universitaire d 'Etudes du Development (IUED).

Rahman, M. D. (2000). Politics and Development of Local Self-Government in Bangladesh. Rajshahi: Rajshahi University Textbooks Board.

Rahman, S. M. A. (2016). Prospects of PPP in Expanding ICT Services in Rural Bangladesh: A Case of Union Digital Centre. International Journal of Economics and Finance, 8(2) 163-170.

Razak N. A., Hassan, Z., Din, R., \& Jusoff, K. (2010). Bridging the Digital Divide: An Analysis of the Training Program at Malaysian TeleCentres. In N. Mastorakis, V. Mladenov, M. Demiralp, \& Z. Bojkovic (Eds.), Proceedings of the 6th WSEAS international conference on applied and theoretical mechanics (pp. 15-23). Athens, Greece: World Scientific and Engineering Academy and Society

Saleheen, S. A. (2015). Public service delivery-role of Union Digital Centre (UDC) and impact on improving governance and development: a case study of Narayanganj District, Bangladesh (MAGD Program Thesis, BRAC University, Bangladesh). Retrieved from http://hdl.handle.net/ 10361/5052

Sarker, A. (2013). Digital Bangladesh: Swapna Puroner Ovijatra (A Journey to fulfill Dreams). Lalmatia, Dhaka: Tothyoseba Barta Songstha (TSB) Publisher

Siddiqui, K. (Ed.) (2005). Local Government in Bangladesh: A Short Introduction. Dhaka: The University Press Limited.

Siddiquee, N. A., \& Faroqi, M. G. (2013). A Road Far Too Long? E-government and the State of Service Delivery in Bangladesh. In E. Halpin, D. Griffin, C. Rankin, L. Dissanayake, \& N. Mahtab (Eds.), Digital Public Administration and E-Government in Developing Nations: Policy and Practice (pp. 206-223). Pennsylvania, USA: IGI Global. 